\title{
Penguatan Dan Pemberdayaan \\ BUMDes (Badan Usaha Milik Desa) Di Desa Batetanginga Kecamatan Binuang Kabupaten Polewali Mandar
}

\author{
${ }^{1}$ Sjuaib Hannan, ${ }^{2}$ Abd Khalik, ${ }^{3}$ Desi Rahman \\ Program Studi Ilmu Pemerintahan \\ Fakultas Ilmu-ilmu Sosial Dan ilmu Pemerintahan \\ Universits Al-Asy'riah Mandar \\ Email: desirahmanjr20@gmail.com, khalikmandar@gmail.com.
}

\begin{abstract}
ABSTRAK
Dalam penelitian ini bertujuan untuk mengetahui sistem pengelolaan Badan Usaha Milik Desa (BUMDes) di Desa Batetangnga yng tanpa adanya pelatihan-pelatihan BUMDes terhadap masyarakat Desa maupun pengurus BUMDes, serta mengetahui faktor pendukung dan penghambat BUMDes Batetangnga. Jenis penelitian ini adalah penelitian kualitatif. Teknik pengumpulan data yakni mengambil data dari pihak yang berwenang dan wawancara mendalam. Hasil kesimpulan menunjukkan bahwa BUMDes di Desa Batetangnga tidak berjalan dengan baik di karenakan : BUMDes di Desa Batetangnga masih sulit untuk dikelola karena masih kekurangan Dana serta ada beberapa masyarakat belum memahami BUMDes sehingga tidak ikut berpartisipasi dalam BUMDes.
\end{abstract}

Kata Kunci : Penguatan Dan Pemberdayaan BUMDes di Desa Batetangnga.

\begin{abstract}
In this study the aim is to find out the management system of Village-Owned Enterprises (BUMDes) in Batetangnga Village without any BUMDes training for the village community or BUMDes management, and to know the supporting and inhibiting factors of the Batetangnga BUMDes. This type of research is qualitative research. Data collection techniques namely taking data from the authorities and in-depth interviews. The conclusion shows that BUMDes in Batetangnga Village is not going well because: BUMDes in Batetan gnga Village are still difficult to manage because they still lack funds and there are some people who do not understand BUMDes so they do not participate in BUMDes.
\end{abstract}

Keywords: Strengthening and Empowerment of BUMDes in Batetangnga Village. 


\section{Penguatan Dan Pemberdayaan BUMDes (Badan Usaha Milik Desa)}

\section{PENDAHULUAN}

Desa di Indonesia merujuk kepada pembagian wilayah administrative yang berada di bawah kecamtan dan dipimpinn oleh seseorang yaitu Kepala Desa atau kepala kelurahan. Desa merupakan suatu kumpulan kecil yang biasa disebut Kampung, atau Dusun.

Istilah Desa berkembang dengan lain sejak berlakunya Otonomi Daerah dan Desa sebagai unit paling rendah tingkatnya dalam struktur pemerintahan Indonesia akan tetapi Desa tetap ada dan tetap berjalan sesuai peraturan yang ada sebelumnya, sesuai dengan peraturan Pemerintah Nomor 72 Tahun 2005 mengenai Desa bahwa Desa adalah kesatuan masyarakat hukum yang memiliki batas wilayah yang berwenang untuk mengatur dan mengurus kepentingan masyarakat setempat, sedangka meurut Undang-undang nomor 6 Tahun 2014 tentang Desa disebut bahwa Desa adalah kesatuan masyarakat hukum yang memiliki batas wilayah berwenang untuk mengatur dan mengurusi urusan pemerintah an Desa.

Adapun kewenangan Desa yang dimiliki yaitu :

1. Menyelenggarakan urusan pemerintahan kewenangan kabupaten/kota yang pengaturannya diserahkan kepada Desa, yaitu urusan pemerintahan yang secara langsung dapat membantu meningkatkan pelayanan terhadap masyarakat.

2. Kewenangan yang sudah ada berdasarkan hak asal usul (UU No. 22 Tahun 1999)

3. Menyelenggarakan urusan pemerintahan lain yang diserahkan kepada Desa.

Desa mempunyai sumberdaya alam yang sangat baik untuk dikelola sesuai dengan potensi Desa yang dimilki sehingga hal tersebut perlu dimobilisasi agar potensi yang dimiliki dapat dirasakan manfaatnya bagi seluruh masyarakat Desa. Namun saat ini masih sangat sedikit Desa yang mampu mengembangkan potensinya. Hal ini disebabkan karena selama ini Desa lebih banyak diposisikan sebagai obyek pembangunan, atau tempat wisata saja sehingga tidak menggantungkan bagi Desa atau masyarakatnya. Rendahnya kreasi sumberdaya manusia di Desa, mengakibatkan tidak berkembangnya sumberdaya alam di Desa itu sendiri, sehingga Desa tidak pernah berkembang. Namun seiring dengan perkembangan yang ada pemerintah pusat mengeluarkan aturan mengenai Desa seperti Buku. Kurniawan (2015 : 9) yang berjudul "Kementrian Desa pembangunan Daerah tertinggal dan Transmigrasi Republik Indonesia". Menilai Undang-Undang yang lahirnya pada Tahun 2014 No. 6 tentang Desa yang akan memberikan konsep baru mengenai manajemen tata kelola Desa secara Nasional. Isi Undang-undang Desa No. 6 Tahun 2014 ialah :

1. Memberikan pengakuan dan penghormatan atas Desa yang sudah ada dengan keberagamannya sebelum dan sesudah terbentuknya Negara Kesatuan Republik Indonesia.

2. Memberikan kejelasan status dan kepastian hokum atas Desa dalam sisstem ketatanegaraan Republik Indonesia demi mewujudkan keadilan bagi seluruh rakyat Indonesia

3. Mendorong prakarsa, gerakan, dan partisipasi masyarakat Desa untuk pengembangan potensi dan Aset Desa guna kesejahteraan bersama.

4. Memjukan perekonomian masyarakat Desa serta mengatasi kesenjangan pembangunan nasional.

Menyadari akan pentingnya potensi di tingkat Desa, Pemerintah melakukan berbagai program untuk mendorong percepatan pembangunan kawasan pedesaan, Oleh karena itu, pemerintah mengeluarkan organisasi baru untuk menguatkan ekonomi diwilayah pedesaan maka organisasi itu ialah "Badan Usaha Milik Desa (BUMDes)" yang di bentuk pada Tahun 2015 


\section{Penguatan Dan Pemberdayaan BUMDes (Badan Usaha Milik Desa)}

NO. 4 dengan maksud untuk mendorong peningkatan ekonomi di Desa. Dengan itu Badan usaha Milik Desa (BUMDes) diartikan untuk mengembangkan potensi Desa yang sesuai kemampuan potensi Desa dan kewenangan Desa.

BUMDes memiliki cara kerja dengan menampung kegiatan masyarakat dalam bidang ekonomi atau potensi Desa ke dalam sebuah bentuk kelembagaan atau badan usaha yang dikelola secara profesional, namun tetap berdasar pada potensi asli Desa melalui kemampuan dan kewenangan Desa, maka BUMDes diharapkan dapat mensti mulus masyarakat untuk berpartisipasi dalam kegiatan membangun dan mensejahterakan Desa mereka.

BUMDes Simpakarannu di Desa Batetangnga yang didirikan pada Tahun 2015. Desa Batetangnga menyertakan modal awal sebesar Rp.50Jt dari Anggaran Dana Desa, modal penyertaan ini sebagai asset Desa yang terpisah di dalam BUMDes dan adapun beberapa unitunit di Desa Batetangnga di antaranya unit pengelolaan Pasar, Traktor Sawah, pengelolaan sampah, Retribusi Wisata/Parkir Penunjung Wisata, Pinjam Usaha Masyarakat dan Perusahaan Daerah Air Minum. Desa Batetangnga merupakan salah satu objek yang dimanfaatkan sebagai permandian, kolam renang, seperti (Rawah bangun, limbong lopi, Salupajaan, Wai Batu, Rawah Indah, Kali Biru, lembah berbunga). Namun seiring perkembangan tersebut berdasarkan hasil observasi dan penelitian ternyata masyarakat dan penglola BUMDes di Desa Batetangnga belum mendapatkan pelatihan-pelatihan tentang penyelenggaraan BUMDes secara ideal serta tidak adanya sosialisasi pengelola BUMDes kepada masyarakat Desa Batetangnga terkait BUMDes, bahkan banyak masyarakat Desa Batetangnga belum mengetahui apa arti BUMDes itu sendiri maka, di sinilah peran Pemerintah Desa Batetangnga dan pengelola BUMDes sangat di butuhkan dalam menjawab segala problematika yang ada. Oleh sebab itu peneliti mengambil judul :

"Penguatan dan Pemberdayaan BUMDes (Badan Usaha Milik Desa) di Desa Batetangnga Kecamatan Binuang, Kabupaten Polewali Mandar".

A. TINJAUAN PUSTAKA

A. Penguatan

Penguatan adalah segala bentuk yang merupakan bagian dari komunikasi terhadap suatu perilaku dalam kegiatan agar dapat meningkatkan komponen-komponen yang terdapat dalam pemberian penguatan antara yang lainnya.

Penguatan merupakan respon yang ditunjukkan secara lisan atau ucapan terhadap suatu perilaku, dari beberapa pengertian penguatan tersebut dapat disimpulkan bahwa penguatan adalah usaha untuk mendorong terjadi suatu proses dalam melaksanakan sebuah kegiatan.

B. Pengertian Pemberdayaan

Alfianti (2014) yang berjudul "Pengaruh Pembelajaran Kooperatif Model Repirocal Teaching Dengan Teknik Example Non Example." mengatakan bahwa pemberdayaan adalah sebuah proses di mana individu atau kelompok, menjadikan cukup kuat untuk berpartisipasi dalam berbagai pengentrolan atas kejadian-kejadian serta lembaga-lembaga yang mempengaruhi. Sehingga dalam proses pemberdayaan tersebut, bisa memperoleh kekuasaan yang dapat mempengaruhi.

C. Badan Usaha Milik Desa (BUMDes)

"Menurut Peraturan Menteri Dalam Negeri Nomor 39 Tahun 2004 BUMDes" adalah usaha Desa yang dibentuk/didirikan oleh pemerintah Desa yang kepemilikan modal dan pengelolaannya dilakukan oleh pemerintah Desa dan masyarakat. 


\section{Penguatan Dan Pemberdayaan BUMDes (Badan Usaha Milik Desa)}

Menurut Manikam (2010 : 19) yang berjudul "Peran Badan Usaha Milik Desa Di Desa." Badan Usaha Milik Desa (BUMDes) merupakan lembaga usaha Desa yang dikelola masyarakat dan pemerintah Desa dalam upaya memperkuat perekonomian Desa dan dibentuk berdasarkan kebutuhan dan potensi Desa.

D. Penguatan dan Pemberdayaan BUMDes.

Penguatan dan Pemberdayaan BUMDes dimaksudkan untuk memutuskan, merencanakan dan mengelola sumber daya yang dimiliki Desa sehingga pada akhirnya desa memiliki kemandirian, kemampuan yang secara ekologi dan sosial, oleh karena itu Penguatan dan Pemberdayaan BUMDes pada hakekatnya membutuhkan kemandirian secara ekologi dan sosial yang selalu dinamis.

Penguatan dan Pemberdayaan BUMDes merupakan konsep yang merangkum nilai-nilai untuk membangun Paradigma baru di Desa Yang Bersifat People-Centered, Participatory, Empowerment And Sustainable (Chamber, 1995) yang berjudul "Lembaga Penelitian , Pendidikan, Penerangan Ekonomi dan Sosial, Pembangunan Desa" Lebih Jauh Chamber Menjelaskan Bahwa Konsep Penguatan dan Pemberdayaan BUMDes tidak hanya semata mata memenuhi kebutuhan dasar tetapi lebih sebagai upaya mencari Alternative Pertumbuhan Ekonomi Desa.

Penguatan dan Pemberdayaan BUMDes sebagai strategi Alternative dalam perkembangan pembangunan perekonomian di desa, terkhusus dalam perkembangan organisasi unit usaha BUMDes. Tetapi kenyataannya pada saat ini BUMDes belum bisa secara maksimal dalam mengimplementasikan, Penguatan dan Pemberdayaan BUMDes merupakan hal yang banyak dibicarakan masyarakat maupun pengurus BUMDes karena terkait dengan kemajuan dan perubahan Desa.

Tujuan Penelitian Untuk mengetahui sistem pengelola penguatan dan pemberdayaan BUMDes Simpakarannu di Desa Batetangnga dan untuk menganalisis pengelolah BUMDes terhadap upaya penguatan dan pemberdayaan BUMDes Simpakarannu.

E. Kerangka Konseptual

Kerangka konseptual Menurut Sapto Haryoko dalam Iskandar (2008: 54) yang berjudul "Metodologi Penelitian Pendidikan dan Sosial" menjelaskan secara teoritis bahwa model konseptual yaitu tentang bagaimana pertautan yang berhubungan dengan variabel-variabel penelitian yang ingin diteliti, yaitu dari pedoman pada penelitian "Penguatan dan Pemberdayaan BUMDes Simpakarannu di Desa Batetangnga Kecamatan Binuang, Kabupaten Polewali Mandar.

Adapun yang digunakan dalam kerangka penelitian ini adalah kebijakan dalam rangka Penguatan dan Pemberdayaan BUMDes Simpakarannu di Desa Batetangnga Kecamatan Binuang Kabupaten Polewali Mandar. Adapaun kebijakan dan alternatifnya yaitu:

1. Aspek Administrasi adalah suatu cara atau strategis untuk memgembangkan Badan Usaha Milik Desa (BUMDes) terlebih pada masalah internalnya, yaitu berkaitan dengan teknis kegiatan informasi yaitu dengn tujuan untuk menyediakan keterangan sert memudahkan BUMDes untuk memperolehnya kembali (arsip) dan dalam suatu hubungan satu sama lain.

2. Aspek Manajemen merupakan suatu aspek yang terkait dengan manajemen pengelola Badan Usaha Milik Desa (BUMDes), yang dimaksud dengan adanya aspek manajemen ini yaitu 


\section{Penguatan Dan Pemberdayaan BUMDes (Badan Usaha Milik Desa)}

mampu megembangkan BUMDes, dan diperlukan adanya manjemen yang ahli, berkompeten serta berkualitas dalam bidangnya.

3. Aspek Ekonomi salah satu strategi pengembangan Badan Usaha Milik Desa (BUMDes) yang bertujuan meningkatkan ekonomi desa dan meningkatkan perekonomian masyarakat Desa. Pengembangan BUMDes dapat dilakukan melalui pengembangan sumber daya alam dan sumber daya manusia yang lebih baik.

4. Aspek Pelayanan merupakan bentuk pelayanan kepada masyarakat maupun dalam tujuan untuk mengukur beberapa perspektif pelayanan termasuk di pelayanan BUMDes yang membutuhkan jasa atau usaha yang dikelola oleh BUMDes.

\section{Metode Penelitian}

Data penelitian yang di pakai dalam penelitian ini adalah metode kualitatif. Metode penelitian kualitatif sering disebut "metode penelitian naturalist" karena penelitiannya dilakukan pada kondisi yang alamiah (natural setting). Peneliti berfungsi sebagai intrumen kunci, teknik pengumpulan data dilakukan secara triangulasi (teknik gabungan), bersifat induktif, analisis data dan hasil penelitian kualitatif yang lebih menekankan pada makna dari pada generalisasi.

Teknik pengumpulkan data yang digunakan peneliti adalah (observasi, wawancara, dan dokumentasi) Teknik Pengumpulan Data ini untuk mengumpulkan bahan-bahan yang

berhubungan dengan judul peneliti dan akan mempermudah penulis didalam menyajikan serta mengungkap sebuah permasalahan yang akan di teliti didalam sebuah penelitian berupa data, fakta, ataupun informasi. Dalam penjabaran sebelumnya sudah dijelaskan bahwasanya peneliti menggunakan metode teknis penelitian kualitatif.

Dalam penelitian ini, yang bertindak sebagai instrument utama dalam penelitian adalah diri sendiri. Menurut Lexy J Moleong (2007 : 5) hanya "manusia sebagai alat" sajalah yang dapat berhubungan dengan responden atau obyek lainnya, dan manusialah yang mampu memamhami kaitan kenyataan-kenyataan di lapangan.

Meskipun demikian, sebagai instrument tetap mencari data yang sesuai dengan kriteria atau judul yang ditentukan serta maksud dan tujuan penelitian. Dalam proses penelitian ini, peneliti menggunakan alat bantu pengumpulan data yaitu berupa buku catatan, handphone, untuk merekam pembicaraan dengan informan, pedoman wawasan maupun data, fakta, gejala dan mencari informasi selama proses penelitian berlangsung.

\section{Hasil Penelitian dan Pembahasan}

Kondisi pemerintahan Desa Batetangnga pada saat sekarang ini adalah dalam keadaan normal dan stabil sesuai dengan harapan masyarakat. Adapun Pemerintahan Desa Batetangnga terdiri dari Kepala Desa, Sekretaris Desa, Kasi Pemerintahan. Kasi Pembangunan, Kasi kesejahteraan, Kaur Umum, Kaur Keuangan atau Bendahara dan Kaur Administrasi. Serta Badan Permusyawaratan Desa (BPD) dan Lembaga Pemberdayaan Masyarakat (LPM) sebagai mitra Pemerintah.

Perlu kami tambahkan bahwa pada tahun 2008 Desa Batetangnga dimekarkan yaitu Dusun kaleok menjadi Desa kaleok pada tahun 2009 maka pada Tahun 2010 Desa Batetangnga menjadi 13 Dusun yaitu: 
Table 4.1

Nama Dusun Batetangnga

\begin{tabular}{|ll|}
\hline \multicolumn{2}{|c|}{ NAMA DUSUN } \\
\hline DUSUN & BIRU \\
\hline DUSUN & KANAN \\
\hline DUSUN & PANANIAN \\
\hline DUSUN & RAPPOAN \\
\hline DUSUN & PASSEMBARANG \\
\hline DUSUN & BARUGA \\
\hline DUSUN & TALLANG BULAWAN \\
\hline DUSUN & ERANBATU \\
\hline DUSUN & PAMU'TU \\
\hline DUSUN & KANANG BENDUNGAN \\
\hline DUSUN & LUMALAN \\
\hline DUSUN & SALEKO \\
Sumber: Data & Primer
\end{tabular}

Tabel 4.3

Keadaan sosial Desa Batetangnga

\begin{tabular}{|c|c|c|c|}
\hline No & Bidang & Volume/Jumlah/Luas & Ket \\
\hline \multirow[t]{6}{*}{$\mathbf{1}$} & Pendidikan & & \\
\hline & $\begin{array}{ll}\text { TK/PAUD } \\
\end{array}$ & 5 & \\
\hline & - $\mathrm{SD}$ & 4 & \\
\hline & - MI & 4 & \\
\hline & - SMP/MTS & 2 & \\
\hline & - SMA/MA & 1 & \\
\hline \multirow[t]{3}{*}{2} & Keagamaan & & \\
\hline & $\bullet \quad$ Mesjid & 5 & \\
\hline & - Mushollah & 19 & \\
\hline \multirow[t]{6}{*}{3} & Kesehatan & & \\
\hline & - $\quad$ Pustu & 1 & \\
\hline & - $\quad$ Polindes & 1 & \\
\hline & - $\quad$ Posyandu & 9 & \\
\hline & - $\mathrm{MCK}$ & 7 & \\
\hline & Bak penapung air bersih & 3 & \\
\hline \multirow[t]{3}{*}{4} & Pertanian & & \\
\hline & - $\quad$ Persawahan & $164 \mathrm{ha}$ & \\
\hline & $\begin{array}{l}\text { Perkebunan } \\
\text { 1. Kakao } \\
\text { 2. Durian } \\
\text { 3. Langsat } \\
\text { 4. Kopi } \\
\text { 5. Kelapa }\end{array}$ & $\begin{array}{l}1090 \mathrm{ha} \\
738 \mathrm{ha} \\
1480 \mathrm{ha} \\
44.5 \mathrm{ha} \\
16.4 \mathrm{ha}\end{array}$ & \\
\hline 5 & Perikanan & & \\
\hline
\end{tabular}




\begin{tabular}{|c|l|c|c|}
\hline No & \multicolumn{1}{|c|}{ Bidang } & Volume/Jumlah/Luas & Ket \\
\hline & $\begin{array}{l}\text { Pembudidayaan/ } \\
\text { pembesaran ikan mas dan ikan nila }\end{array}$ & 5. ha \\
\hline & $\begin{array}{l}\text { Kolam Pembibitan Ikan mas dan ikan } \\
\text { nila }\end{array}$ & & \\
\hline
\end{tabular}

Sumber: Diolah dari data sekunder Desa Batetangnga Tahun 2010

Kondisi Pemerintahan Desa Batetangnga

Kondisi pemerintahan Desa Batetangnga pada saat sekarang ini adalah dalam keadaan normal dan stabil sesuai dengan harapan masyarakat. Adapun Pemerintahan Desa Batetangnga terdiri dari Kepala Desa, Sekretaris Desa, Kasi Pemerintahan. Kasi Pembangunan, Kasi kesejahteraan, Kaur Umum, Kaur Keuangan atau Bendahara dan Kaur Administrasi. Serta Badan Permusyawaratan Desa (BPD) dan Lembaga Pemberdayaan Masyarakat (LPM) sebagai mitra Pemerintah.

Hasil Penelitian, Desa Batetangnga pada tanggal 01 Januari 2015 mendirikan badan usaha milik desa atau yang sering di sebut BUMDes dan di beri nama BUMDes Simpakarannu. Di tahun 2019-2020 merupakan pergantian kepengurusan BUMDes yang ke-3 pada awal kepengurusan periode ini keadaan kas BUMDes sebesar nol rupiah tetapi dengan asset unit usaha yang masih bisa berfungsi. Kodisi ini dijadikan sebagai dasar penyusunan data Pengelolaan BUMDes Batetangnga.

Pembentukan Unit Usaha BUMDes Batetangnga. Pembentukan unit-unit usaha BUMDes Batetangnga didasarkan pada peta konsep yang telah dibuat dalam potensi Desa. Unit-unit BUMDes Batetangnga, sebagai berikut:

A. Usaha lama

1. Unit usaha Pasar Desa Batetangnga

2. Unit Pengelolaan Sampah

B. Usaha baru

1. Unit Usaha Pinjaman Usaha Masyarakat (PUM)

2. Unit Usaha Retribusi Pariwisata/Parkir Kendaraan Pengujung

3. Unit Usaha Penyediaan Air Minum (PDAM)

Adapun berpedomaan Dasar Hukum Pembentukan BUMDes di Desa Batetangnga untuk dapat menjalankan kegiatan usaha BUMDes Batetangnga pada :

a. PP No. 43 tahun 2014 dan PP No. 47 tahun 2015 tentang perubahan PP No. 43 tahun 2014 tentang peraturaan pelaksanaan UU Desa, khususnya BAB II tentang terkait dengan pendirian BUMDes.

b. Peraturan Mentri Desa, pembangunan Daerah tertingal dan Transmigrasi Republik Indonesia Nomor 4 tahun 2015 tentang pendirian, pegurusan, dan pengelolaan, dan pembubaran BUMDes;

c. Peraturan Desa Batetangnga Nomor 1 tahun 2015 tentang Pendirian Badan Usaha Milik Desa (BUMDes) Batetangnga.

Keseriusan pemerintah daerah terhadap keberlansungan BUMDes pada pemeritah Desa merupakan sebuah gerakan dinamis dalam menjawab pemenuhan kebutuhan masyarakat baik dari segi perekonomian, pembangunan, budaya dan sosial politik.

Peraturan Menteri Dalam Negeri Nomor 39 tahun 2010 tentang Badan Usaha Milik Desa, menyebutkan bahwa: untuk meningkatkan kemampuan keuangan pemerintah Desa dalam penyelenggaraan pemerintahan dan meningkatkan pendapatan masyarakat melalui berbagai 


\section{Penguatan Dan Pemberdayaan BUMDes (Badan Usaha Milik Desa)}

kegiatan usaha ekonomi masyarakat pedesaan, didirikan Badan Usaha Milik Desa sesuai dengan kebutuhan dan Potensi Desa.

Kemudian di dalam Peraturan Menteri Desa, Pembangunan Daerah Tertinggal, Dan Transmigrasi Republik Indonesia dalam Pasal 2 Peraturan Meneteri Desa Nomor 4 Tahun 2015 Tentang Pendirian, Pengurusan dan Pengelolaan, Dan Pembubaran Badan Usaha Milik Desa yaitu Pendirian BUMDes dimaksudkan sebagai upaya menampung seluruh kegiatan di bidang ekonomi atau pelayanan umum yang dikelola oleh Desa.

Hal ini dikarenakan: pertama BUMDes merupakan salah satu strategi kebijakan untuk menghadirkan institusi Negara (Kementerian Desa PDTT) dalam kehidupan bermasyarakat dan bernegara di Desa (selanjutnya disebut Tradisi Berdesa). Kedua, BUMDes merupakan salah satu strategi kebijakan membangun Indonesia dari pinggiran melalui pengembangan usaha ekonomi Desa yang bersifat kolektif. Ketiga, BUMDes merupakan salah satu strategi kebijakan untuk meningkatkan kualitas hidup manusia Indonesia di Desa. Oleh karena itu, Pengelolaan BUMDes pada dasarnya memiliki peran penting dalam upaya untuk memberdayakan masyarat dalam perekonomian.

Dalam pengelolaaan BUMDes Batetangnga masih banyak masyarakat yang masih kurang paham tentang pengelolaan yang sudah di kelola oleh pengelola BUMDes, namun pada hakikatnya sebagaimana hasil peneliti yang dipaparkan dari tanggapan 13 masyarakat yang dimintai keterangan ternyata kemudian ada beberapa point yang menjadi faktor penunjang terlaksanany a penyelenggaraan BUMDes dan juga tidak berjalannya BUMDes desa Batetangnga secara ideal yakni :

1. Pola Komunikasi

Komunikasi merupakan suatu hal yang penting dalam sebuah penyelenggaraan peerintah karena menyangkut proses penyampaian informasi, kejelasan informasi, dan konsistensi informasi yang disampaikan. Keterampilan berkomunikasi akan menjamin berjalannya fungsi kegiatan unit BUMDes dan berkomunikasi yang baik dapat berkontribusi pada pengelola BUMDes yang baik.

"Kurangnya pengetah uan dan keterangan pengelola BUMDes dalam teknologi bidang administras seh ingga pengelola BUMDes batetangnga kurang memahami susunan administrasi" (wawancara 23 maret 2020)

2. Sumberdaya

Selain harus dijalankan dengan cermat, jelas dan komitmen maka juga di perhatikan sumberdaya agar pengelola bisa berjalan dengan efektif. Dengan demikian sumberdaya juga mempengaruhi keaktifan Pengelola BUMDes serta masyarakat desa batetangnga, dan meningkatkan perekonomian Desa serta unit-unit BUMDes.

"Seperti yang di sampaikan informan Ibu Rauda kalau bisa lagi ditingkatkan sumber air bersih di Desa ini yang dikelola BUMDes maka sangat membatu saya dalam menjaual nasi kuning serta masyarakat lainnya."(wawancara 23 maret 2020)

3. Pertanggung jawaban

Pertanggung jawaban dari pengurus BUMDes selama ini sudah berjalan dengan baik akan tetapi hal ini bisa menjadi buruk jika di topang oleh lingkungan kegiatan pengelolaan BUMDes dan pihak masyarakat yang tidak mengerti dengan kelangsungan unit-unit BUMDes.

"Menurut pengurus BUMDes kegiatan ini bisa berjalan baik dan tepat jika di topang ol eh sifat kesadaran masyarakat." (wawancara 23 maret 2020)

4. Informasi

Dalam hal ini Informasi belum berjalan dengan baik, informasi bisa dijadikan bahan evaluasi akan kinerja dari pengelola BUMDes dan walaupun sudah di bantu oleh pemerintah 


\section{Penguatan Dan Pemberdayaan BUMDes (Badan Usaha Milik Desa)}

akan tetapi penguruslah yang bertanggung jawab secara penuh dalam pengelolaan dan pengembangan BUMDes.

5. Kredibilitas

Tahap kredibilitas ini tidak menjadi permasalahan pengelolaan BUMDes, karena pengurus BUMDes sudah mampu menunjukan unit-unit mereka lewat kegiatan BUMDes, seperti Pengelolaan Pasar, Pengelolaan Sampah, dan Traktor Sawah dan sampai saat ini masih berjalan akan tetapi di harap kedepan BUMDes di Desa Batetangnga ini bisa memberikan kontribusi demi kemakmuran masyarakat Desa.

6. Struktur Birokrasi

Struktur Birokrasi dalam pelaksanaan BUMDes juga mempunyai pengaruh penting. Birokrasi merupakan salah satu badan yang paling penting dalam kejelasan sebuah kegiatan. Birokrasi secara keseluruhan baik secara sadar atau tidak sadar memilih bentuk-bentuk organisasi untuk kesepakatan dalam berorganisasi. Struktur organisasi yang dimaksut dalam hal ini adalah pengelolaan BUMDes.

Dalam hal ini terdapat empat aspek yang mempengaruhi birokrasi yaitu :

A. Aspek administrasi

Aspek administrasi adalah suatu cara atau strategis untuk mengembangkan BUMDes batetangnga terlebih pada masalah internalnya yang berkaitan dengan teknis kegiatan informasi dengan tujuan untuk menyediakan keterangan serta memudahkan BUMDes untuk memperolehnya dalam suatu hubungan satu sama lain.

B. Aspek manajemen

Aspek manajemen merupakan suatu aspek yang terkait dengan manajemen pengelola BUMDes, dan yang dimaksud dengan adanya aspek manajemen ini yaitu mampu mengembangkan BUMDes dan diperlukan adanya manajemen ahli berkompeten serta berkualitas dalam bidangnya. Adapun Aspek Manajemen BUMDes Batetangnga yaitu : Pengelola BUMDes di Desa Batetangnga kurang memperhatikan manajemen yang sudah yang dikelola, baik dari segi proses perencanaan, pengorganisasian, pengkoordinasian dan pengontrolan serta unit-unit usaha BUMDes yang sudah ada. Dan jika diperbaiki maka akan lebih efektif serta efesien dalam mencapai sasarannya.

C. Aspek ekonomi

Aspek ekonomi adalah salah satu strategis pengembangan yang bertujuan untuk meningkatkan perekonomian desa dan meningkatkan pengembangan BUMDes di desa batetangnga dapat dilakukan melalui pengembangan sumberdaya alam dan sumberdaya manusia yang lebih baik. Keuntungan hasil yang didapat BUMDes Batetangnga :

a. Dana Operasional Pengurus (Dop) $=$ Rp. 14.201.500

b. Pendapatan Asli Desa $(\mathrm{Pad})=$ Rp. 5.782.500

c. Dana Sosial $(\mathrm{Ds})=$ Rp. 2.191.000

d. Dana Penambahan Modal Usaha $=$ Rp. 2.988.500

e. Dana Pelatihan Pengurus (Dpp) $=$ Rp. 1.991 .500

f. Dana Cadangan (Dc) $=$ Rp. 1.991.500

D. Aspek Pelayanan

Aspek pelayanan merupakan kemampuan untuk memberikan apa yang dijanjikan dengan tepat serta akurat, misalnya apakah ketika kita berlanggan dengan pihak ketiga atau kepada masyarakat maka akan mampu memberikan pelayanan baik sesuai yang diinginkan. Adapun bentuk pelayanan di BUMDes Batetangnga yaitu :

1) Kurangnya pengelola BUMDes dalam meningkatkan pelayanan masyarakat di akibatkan mereka terlalu fokus dalam bidang mereka masing-masing sehingga pelayanan masyarakat 


\section{Penguatan Dan Pemberdayaan BUMDes (Badan Usaha Milik Desa)}

terkendala seperti bagaimana respon pengelola BUMDes dalam melayani masyarakat yang menggunakan unit-unit usaha BUMDes Batetangnga.

7. Fasilitas

Dalam hal ini sarana dan prasarana sangat diperlukan demi keberhasilan suatu kegiatan terkhusus di kegiatan BUMDes di Desa Batetangnga, memahami apa yang harus dilakukan dan melakukan tugasnya juga sebaiknya memiliki fasilitas seperti bagunan kantor untuk melakukan koordinasi serta perlengkapan dan perbekalan lainya yang mendukung proses pengelolaan BUMDes tersebut.

Keberhasilan dalam melaksanakan sebuah tanggung jawab sesungguhnya juga banyak dipengaruhi oleh faktor-faktor diluar seperti faktor sosiologi, budaya, atau kultur masyarakat.

Suatu pengelolaan sering kali melibatkan beberapa lembaga atau organisasi dalam proses pengelolaan sehingga diperlukan koordinasi yang efektif antar lembaga-lembaga dalam mendukung keberhasilan penguatan dan pemberdayaan BUMDes

Dalam penelitian ini peneliti bertatap muka langsung dengan beberapa individu sebagai anggota masyarakat yang telah diwawancarai. Penyelenggaraan BUM Des Batetangnga menjadi obyek penelitian dari pembicaraan masyarakat serta aktifitas yang mencakup keseluruhan dari informasi, sehingga telah dipilih 13 orang masyarakat setempat sebagai informan untuk memberikan keterangan secara lengkap mengenai penguatan dan pemberdayaan BUMDes dan juga kendala pelatihan BUMDes.

\section{Kesimpulan}

Sebagai hasil akhir penelitian tentang penguatan dan pemberdayaan BUMDes untuk meningkatkan kesejahteraan perekonomian Desa, dan dapat diambil kesimpulan sebagai berikut

1. Sitem Pengelola BUMDes di Desa Batetangnga dalam melaksanakan fungsi dan tanggung jawabnya. Berdasarkan hasil penelitian belum maksimal di karenakan masih kurangnya sosialisasi kepada masyarakat maupun pengurus BUMDes sehingga masyarakat yang berpartisipasi masih sangat kurang, sehingga mengakibatkan masih rendahnya tingkat status kepahaman masyarakat terkait dengan BUMDes serta di lain pihak dikarenakan kesibukan masyarakat Desa Batetangnga mencari nafka untuk memenuhi kebutuhannya sehari-hari.

2. Adapun faktor penghambat dan faktor pendukung Penguatan dan Pemberdayaan BUMDes di Desa Batetangnga dari hasil pengamatan peneliti selama dilapangan adalah sebagai berikut :

a. Faktor penghambat

Keberadaan BUMDes dalam melaksanakan program usaha tidak bisa lepas dari anggaran yang dimiliki, sebagai lembaga usaha keberadaan untuk hidup dan berkembang. Kesiapan dana usaha di Desa Batetangnga sangat terbatas yang dimiliki.

Keberadaan BUMDes di Desa Batetangnga sebagai alternative dalam mengembangkan usaha Desa dan perekonomian masyarakat Desa. Berdasarkan wawancara mendalam dengan Pengelola BUMDes pada tanggal 16 Juli 2020 menyebutkan bahwa keberadaan program BUMDes di Desa kami sudah baik akan tetapi keberadaan anggaran kami tidak mencukupi makanya pelatihan BUMDes di Desa kami tidak dilaksanakan dengan secara bertahap dan juga tidak adanya kesadaran masyarakat akan pentingnya organisasi BUMDes sehingga ada beberapa masyarakat tidak paham mengenai BUMDes.

b. Faktor Pendukung

Komitmen pemerintah terhadap keberlansungan BUMDes dibuktikan dengan pemberian dana dalam usaha mengembangkan BUMDes. Berdasarkan wawancara mendalam dengan sekretaris BUMDes pada tanggal 16 Juni 2020 menyebutkan bahwa peran pemerintah dalam 


\section{Penguatan Dan Pemberdayaan BUMDes (Badan Usaha Milik Desa)}

penanggulangan kemiskinan dan pemberdayaan Desa melalui BUMDes sangat tinggi. Ini dibuktikan dengan suntikan dana BUMDes berasal dari dana Desa. Pemerintah sangat mendukung peningkatan kesejahteraan pada tingkat Desa selain program BUMDes pemerintah melaksanakan program-program lain yang berbasis pada masyarakat Desa.

Dalam penelitian ini peneliti bertatap muka langsung dengan beberapa individu sebagai anggota masyarakat yang telah diwawancarai. Penyelenggaraan BUMDes Batetangnga menjadi obyek penelitian dari pembicaraan masyarakat serta aktifitas yang mencakup keseluruhan dari informasi, sehingga telah dipilih 13 orang masyarakat setempat sebagai informan untuk memberikan keterangan secara lengkap mengenai penguatan dan pemberdayaan BUMDes dan juga kendala pelatihan BUMDes.

\section{Daftar Pustaka}

Arikunto Suharsimi. (2008). Manajemen Penelitian. Jakarta: Rineka Cipta.

Alfianti, dkk. 2013. Pengaruh Pembelajaran Kooperatif Model Reciprocal Teaching Dengan Teknik Example Non Example Terhadap Berpikir Kritis Jember. Diakses tanggal 10 maret 2015).

Chambers, R. 1995, Lembaga Penelitian, Pendidikan, Penerangan Ekonomi dan Sosial, Pembangunan Desa Mulai dari Belakang. Jakarta.

Bogdan dan Taylor. (2012). Metodologi Penelitian Kualitatif. Bandung: Remadja Karya

Djamarah, Syaeful Bahri (2005) Guru dan Anak Didik dalam Interaksi Anak Didik, Rineka Cipta, Jakarta

Fajar Sidik. Menggali Potensi Lokal Mewujudkan Masyarakat Desa Melalui Program Peningkatan Pemberdayaan Masyarakat Perdesaan Di Kecamatan Kundur Barat Kabupaten Karimun (Studi Pada Desa Sawang Laut Dan Desa Gemuruh). Jom FISIP Volume 1 No.2 Oktober 2014

Fitriska, K. (2003). Strategi Pengembangan Badan Usaha Milik Desa dalam Meningkatkan Kesejahteraan Masyarakat Desa di Desa Lancang Kuning Kecamatan Bintang Utara. Naskah Publikasi

Kurniawan, B. (2015). Desa Mandiri, Desa Membangun. Jakarta: Kementerian Desa, Pembangunan Daerah Tertinggal, Dan Transmigrasi Republik Indonesia.

Lexy J Moleong. (2011). Metode Penelitian Kualitatif. Bandung: PT Remaja Rosda Karya.

Manikam. 2010. Peran Badan Usaha Milik Desa Di Desa Ngepo Sari Kecamatan Semanu Kabupaten Gunung Kidul, Yogyakarta: Ilmu Pemerintahan FISIP UMY

Muhadam Labolo, (2007) Memahami Ilmu Pemerintahan.Jakarta; PT RajaGrafindo Persada

Maleong, L. J. 2010. Metode Penelitian Kualitatif, Bandung: Remaja Rosda Karya

Pius A. Sartanto dan M. Dahlan al-Barry,Kamus Ilmiah Populer, (Surabaya: Arkola,1994) hal. 625.

Sutoro Eko, et., al., Desa Membangun Indonesia, Yogyakarta, Cetakan Pertama FPPD 2014. 
Sapto, Haryoko, 2008. Metodologi Penelitian Pendidikan dan Sosial (kuantitatif dan kualitatif), Gaung Persada Press, Jakarta.

Suharyanto, Hastowiyono, Pelembagaan BUMDes (Yogyakarta: Forum Pengembangan Pembaharuan Desa)

Suhendra, K. (2006) Peranan Birokrasi dalam Pemberdayaan Masyarakat. Bandung: STKSPRESS

Toriqi, A. (2015). Analisis Yuridis Tentang Pengaturan Pengelolaan Anggaran Dana Desa Berdasarkan Otonomi Desa (Doctoral dissertation, Fakultas Hukum).

\section{Undang-undang}

- Undang-undang 23 Tahun 2014 Tentang Pemerintah Daerah

- Permendesa Nomor 4 Tahun 2015 Tentang BUMDes

- Undang-undang Pemerintah Nomor 72 Tahun 2015 Tentang Desa, penjelasan mengenai Desa

- Peraturan Daerah Kabupaten Polewali Mandar Nomor 4 Tahun 2007 Tentang "Pedoman Pembentukan dan Pengelolaan Badan Usaha Milik Desa“"

- Undang-Undang Nomor 6 Tahun 2014 tentang Desa 